\title{
Understanding Farmers' Perceptions and Risk Responses to Climate Change in China
}

\begin{abstract}
Agriculture is likely to bear the brunt of the impacts of climate change. The extent to which these impacts are felt depends in large part on the extent of adaptation in response to climate change. The overall aim of this paper is to attempt to identify farmers' knowledge, perceptions and risk responses towards climate change (or potential change). In order to achieve this goal, several specific objectives are pursued. First, the paper investigates whether or not farmers have perceived the long-term climate change and extreme weather events. Second, the paper describes how farmers respond to climate change and tries to assess the determinants of their adaptation. Based on data collected from a survey among farm households in three provinces in rural China, the findings demonstrate that farmers are aware of climate variability and identify the rising temperature, decreasing precipitation and the increasing frequency of drought. Only about $25 \%$ of farmers are willing to adjust their farming structures as a risk reaction. Household size, wealth, farm size, and the number of plots are found to be important factors that influence farmer adaptive capacity. Implications for policymaking on agriculture and adaptation to climate change will be to focus on providing farmers with information about the climate in time and facilitating enhancement of their adaptive capacity.
\end{abstract}

Keywords: perception, climate change, agriculture, risk reaction, farmers, China

Manuscript received June 15, 2015; accepted September 10, 2015

Yang-jie Wang

Business School of Central South University, Collaborative Innovation Center of Resource-conserving \& Environment-friendly Society and Ecological Civilization, Changsha 410083, China

Xiao-hong Chen ( $ه)$

Business School of Central South University, Collaborative Innovation Center of Resource-conserving \& Environment-friendly Society and Ecological Civilization; Hunan University of Commerce, Institute of Big Data and Internet Innovation, Changsha 410083/410205, China

Email: csu_cxh@163.com

\section{Introduction}

It is now beyond scientific doubt that the global climate change is one of the most critical environmental problems to face the world this century. Future climate change will cause changes in temperature and precipitation patterns thus altering the hydrologic cycle, global circulation patterns and local weather patterns (IPCC, 2014a). These changes of climate and reduced results may pose substantial risks to natural and human systems, particularly in China where climate change is expected to be felt strongly (ECSNCCA, 2011; IPCC, 2014b). During the 20th century, for example, China experienced a noticeable warming trend, the average annual temperature rose by $0.5^{\circ} \mathrm{C}$ to $0.8^{\circ} \mathrm{C}$. By 2050 , China's temperature is expected to further increase by $2.5^{\circ} \mathrm{C}$ to $4.6^{\circ} \mathrm{C}$ (ECSNCCA, 2011).

The change of climate and its variability influences many aspects of society, of which, the concerns of the impaction agricultural production have been growing (Wang et al., 2009). Indeed, agriculture is a key sector where future climate change is estimated to have large detrimental effects (Deschênes \& Greenstone, 2007). In particular, with their ultra-weather-sensitive agrarian economy, developing countries and their economic development are likely to suffer tremendously from the threat of climate change (Mendelsohn \& Dinar, 2009). As such, numerous reports have provided assessments of the potential impacts of climate change on agriculture ( Schlenker \& Roberts, 2009; Holst, Yu, \& Grun, 2013). In China, the concern of the influence of climate change on food security is also rising (Piao et al., 2010; NDRC, 2012). As emphasized in the government report, the agricultural and food security in China may face more challenges due to climate change (ECSNCCA, 2011). Xiong, Conway, Lin, and Holman (2009) find that the expected effects of temperature increases and precipitation decreases - under the worst case scenario - could lead to a drop in China's rain-fed yields of rice, wheat and maize of between $20 \%$ to $36 \%$ over the next 20 to 80 years.

In face of the challenge of climate change, adaptation at local levels has been suggested as important responses to 
address climate change impacts on agricultural production (FAO, 2007). Much recent conceptual and empirical research focuses on farmers' adaptation to climate change and identifying the factors that diminish or enhance their adaptive capacity (Smit \& Skinner, 2002). These studies and others like them have documented a large number of climate change adaptation options ranging from adjustments to tillage practices and water conservation techniques to crop diversification (Deressa, Hassan, Ringler, Alemu, \& Yesuf, 2009; Di Falco, Veronesi, \& Yesuf, 2011; Wang, Huang, \& Wang, 2014). In China, farmers' adaptation to climate change can be generally categorized by engineering and non-engineering strategies (Chen, Wang, \& Huang, 2014; Huang, Wang, \& Wang, 2015). In the application of these strategies, constraints on adaptations have revolved around issues such as lack of institutional capacity, lack of financial and human resources, lack of information on climate change, lack of technology and lack of education among others (Wang, Huang, \& Wang, 2014; Di Falco, Veronesi, \& Yesuf, 2011).

While such research remains significant and have enhanced climate change adaptation science, they do not represent the complete picture. Relatively little attention has been paid to the role of perceptions of local people in the process of adaptation. In effect, perception of hazard risk has long been recognized as a critical determinant of human response to environmental shocks and change (Frank, Eakin, \& López-Carr, 2011). As Maddison (2007) points out, adaptation to climate change requires that farmers first perceive that the climate has altered, and then identify useful adaptation measures and implement them. If farmers learn gradually about the change in climate, they will also learn gradually about the best techniques and adaptation options available. Until now, while there is an increasing number of studies on people's perceptions of climate change in the world (Maddison, 2007; Byg \& Salick, 2009; Bryan, Deressa, Gbetibouo, \& Ringler, 2009; Tucker, Eakin, \& Castellanos, 2010), the analysis on local perceptions of climate change in rural China is still lacking. Importantly, understanding farmers' perceptions is found to be critical in guiding policy responses on adaptation (Tucker, Eakin, \& Castellanos, 2010). In China, smallholder farmers play an important role in decision making processes with respect to climatic risks, determining how the sector will be affected by climate change and influencing policy response.

In contributing to this area of study, this paper intends to capture the extent of farmers' knowledge and perceptions of climate variability and environmental change and reactions they would have in their farming practices in response to these changes (or potential changes). In order to achieve this goal, several specific objectives are pursued:
1) to discern and interpret local farmer's knowledge and perceptions towards climate change; 2 ) to examine the risk reactions of farmers to the changes of climate; and 3) to identify whether famers with different demographic characteristics have different risk reactions. Answers to these questions will inform scholars and policy makers alike how to provide effective national and local policies on adaptive capacity building in agricultural production.

The remainder of this paper will be organized as follows. The next section describes the methodologies, including the dataset, from a unique farm household survey of a total of 620 farmers conducted in November 2005 in three provinces of China, and the econometric model for determinant analysis. The following section uses the data to investigate farmers' knowledge and perceptions on climate change. The third section analyzes in a multivariate framework farmer response behavior to climate change and its determinants. The final section gives the conclusion.

\section{Methodologies}

\subsection{Survey design}

The data used in this study comes from a large field survey, administered through personal interviews during November and December 2011 (Wang, Huang, \& Wang, 2014). This survey covers 3 provinces of 3 large river basins in China. These provinces are Shanxi in the Yellow River Basin, Qinghai in the Northwest Interior River Basin, and Guangdong in the Pearl River Basin. When selecting provinces for field survey, not only have the authors taken into account the differences in climate and water resources between Northern and Southern regions, but diversified economic development has also been considered. For example, Shanxi and Qinghai have less precipitation, while Guangdong has more abundant precipitation and water resources (NBSC, 2012). These regions also represent high (Guangdong Province), middle (Shanxi Province) and low (Qinghai Province) levels of economic development.

In each province, the authors applied the stratified random sampling approach to select samples. First, three counties from each province were randomly selected ${ }^{1)}$. Within each county, three townships and two villages from each township were randomly selected ${ }^{2}$. Finally, the authors selected 10 households randomly in each village for an interview. As a result, the total samples in this survey include 10 counties, 31 townships, 63 villages, and 620 households in 3 provinces.

In the samples the major respondents of the questionnaires are household heads. To avoid potential bias, before the authors started conducting the formal survey, the

1) In Guangdong Province, the authors added one more county as the province has more diversified extreme weather events.

2) In Qinghai Province, the authors selected 4 townships from each county, 2 villages per township in 2010 and 3 villages per township in 2011 to reflect more diversified agriculture in the province. 
authors provided strict indoor training for all enumerators and then carried out field training for these enumerators. In addition, to avoid any influence of opinions from other members of the family or other farmers, every respondent in each household was made to hold a face-to-face interview in his or her residence privately.

The surveys were designed to evaluate farmer attitudes and knowledge about an array of climate issues with both fixed-responses and open-ended questions. The fixedresponse questions and the possible alternative answers were read to interviewees, while the open ones were asked subsequently to gain an in depth understanding of their answers. These topics included issues such as the perceived change of climate change (both annual temperature and rainfall) and frequency of extreme weather events in the past ten years. In this research four areas of questions were focused on relating to the respondents: 1) knowledge about climate change, 2) perceptions of climate change and variability, 3) perceptions towards relationship between GHG emission and climate change, 4) risk reactions to possible extreme weather events (Table 1). In addition, some crop production information of the household, and some demographic information of the respondents (gender, education level, age, residence location) and household characteristics (household size, acreage of land owned, and wealth) were also collected. The latter information would probe deeper into the insights and perspectives of farmers.

In this research the authors mainly dealt with four major issues. The first concerned farmers' knowledge about climate change. More specifically, the authors asked them if they heard about "climate change" and if so, what they had heard about the temperatures becoming higher or lower? By use of an open question, the authors additionally asked farmers to identify the main channels of receiving knowledge about climate change. The second issue concerned farmers' perceptions of climate change; the authors asked the following two sets of questions about farmers' perceptions on long-term changes in mean temperature, mean precipitation and the frequency of extreme weather events (such as drought, flood, and frost) in the past ten years. The third issue concerned farmers' knowledge towards the relationship between GHG emission and climate change. The authors want to specify whether relationship exist between farmers' perceptions of climate change and chemical fertilizer application. The last issue concerned farmers' reactions to three possible extreme weather events; whether they would adjust cropping structure (changing to different crops) when the weather becomes hotter and rainfall decreases.

\subsection{Analysis}

Survey results were entered into STATA version 11.2 for analysis. Basic descriptive statistics were used to describe the sample population and responses to each question and to ascertain the distribution of responses by geographic location. The authors mainly focus on farmers' knowledge of climate change and GHG emission, farmers' perceptions on long term climate change and extreme weather events (drought and flood), and farmers' risk responses to climate change.

Moreover, the authors also conducted a Probit regression model to examine the determinants of farmers' reactions:

$$
A_{i}=\alpha+\sum_{j=1}^{8} \beta_{j} Z_{j}+\delta P+u_{i},
$$

where subscript $i$ represents $i^{\text {th }}$ household. The dependent variable, $A_{i}$, is farmer's risk response to climate change. It is a dummy variable, equaling 1 if the farmer takes an adaptive action to deal with climate change and 0 otherwise. The subscript $j$ represents $j^{\text {th }}$ farmer-specific characteristic (on each household $i$ ) and in this analysis there are six exogenous demographic and socioeconomic characteristics (as seen in Table 2), including household size, gender, education and age of household head (years), family wealth measured by the value of household's durable consumption assets $(1,000 \mathrm{CNY})$, farm size in a household (hectare), the number of plots and walking time of farmers' residence from the village border, that are represented by the variable $Z_{j}$. The variable $P$ represents a set of county dummies used to control the county-specific factors. The term $u_{i}$ is the error term. The coefficients to be estimated include $\alpha, \beta$, and $\delta$. The authors are interested in the coefficient $\beta$ which captures the impacts of various socioeconomic factors on the farmer's reaction decision to climate change. Summary statistics of the independent and dependent variables are in Table 2 and Table 8, respectively.

\section{Farmers' perceptions on climate change}

\subsection{Individual and household socio-economic characteristics}

In the household survey, the authors also collected detailed information on their basic social-economic characteristics. Table 2 reports descriptive statistics for the socio-economic characteristics of respondents and household in the survey year. It can be seen that in the 620 surveyed households from three provinces in China, the average age of the household head is 51 . About $96 \%$ of household heads are male, only $4 \%$ of household heads are female. On average, each household has $17 \mathrm{mu}$ (1.13 ha) of cultivated land and the per capita cultivated land area is $3.6 \mathrm{mu}$. The average number of plots per household is as high as 9, and the average asset value of family durable consumer goods is 0.112 million CNY. With respect to education, on average, household heads have about 7 years of education. As for the residence location, most of the farmers dwell in villages 
Table 1

Questions Asked of Farmers to Examine Their Response to Climate Issues

\begin{tabular}{|c|c|c|}
\hline Questions & & Responses \\
\hline \multicolumn{3}{|c|}{ Knowledge (select one answer) } \\
\hline$(1)$ & Have you heard about the concept of global climate change? & Yes/No \\
\hline$(2)$ & If yes, is the temperature reported to be rising or decreasing? & Rising/Decreasing/Do not know \\
\hline (3) & Have you heard about greenhouse gas emissions? & Yes/No \\
\hline (4) & $\begin{array}{l}\text { If yes, do you think there is a relationship between application of fertilizer and } \\
\text { greenhouse gas emissions? }\end{array}$ & Yes/No/Do not know \\
\hline$(5)$ & Do you think heavy fertilization will affect local water quality? & Yes/No/Do not know \\
\hline \multicolumn{3}{|c|}{ Perceptions (select one answer) } \\
\hline$(6)$ & How do you believe has the annual temperature changed over the last 10 years? & $\begin{array}{l}\text { Increased/Decreased/unchanged/Do not } \\
\text { know }\end{array}$ \\
\hline (7) & $\begin{array}{l}\text { How do you believe has the annual rainfall changed over the } \\
\text { last } 10 \text { years? }\end{array}$ & $\begin{array}{l}\text { Increased/Decreased/unchanged/Do not } \\
\text { know }\end{array}$ \\
\hline$(8)$ & How do you believe have drought conditions changed over the last 10 years? & $\begin{array}{l}\text { Increased/Decreased/unchanged/Do not } \\
\text { know }\end{array}$ \\
\hline (9) & How do you believe have freezing weather conditions changed over the last 10 years? & $\begin{array}{l}\text { Increased/Decreased/unchanged/Do not } \\
\text { know }\end{array}$ \\
\hline$(10)$ & How do you believe have flood disasters changed over the last 10 years? & $\begin{array}{l}\text { Increased/Decreased/unchanged/Do not } \\
\text { know }\end{array}$ \\
\hline \multicolumn{3}{|c|}{ Attitudes (Risk reactions to climate change) (select one answer) } \\
\hline (11) & $\begin{array}{l}\text { Given all other conditions remain the same, if the temperature is rising in the long } \\
\text { run, will you switch to other crops? }\end{array}$ & Yes/No \\
\hline$(12)$ & If yes, which crops are you most likely to switch to? & Open \\
\hline (13) & $\begin{array}{l}\text { Given all other conditions remain the same, if the precipitation is increasing in the } \\
\text { long run, will you switch to other crops? }\end{array}$ & Yes/No \\
\hline (14) & If yes, which crops are you most likely to switch to? & Open \\
\hline$(15)$ & $\begin{array}{l}\text { Given all other conditions remain the same, if the precipitation is decreasing in the } \\
\text { long run, will you switch to other crops? }\end{array}$ & Yes/No \\
\hline (16) & If yes, which crops are you most likely to switch to? & Open \\
\hline
\end{tabular}

not far from each other, the walking time from home to the village border is about 0.58 hours. Household size varies from 1 to 12 members with a mean of 4.9 persons.

3.2 Knowledge of farmers about climate change and GHG emission.

Interviewees were asked about their knowledge related to climate change (Table 1, Questions (1) and (2)). Table 3 reports the percentage distributions of responses to these questions. Over half of the farmers $(52.9 \%)$ indicated that they knew the concept of global climate change (Question (1)). There is not obvious knowledge difference among regions. For example, about $47.5 \%, 57.2 \%$, and $55.5 \%$ answered "yes" in Guangdong, Shanxi, and Qinghai respectively. The second question (Question (2)) was a follow-up conditional on having answered "yes" in Question (1). As shown in Table 3, conditional on knowing the concept of climate change, a vast majority $(91.2 \%)$ of the respondents answered that the temperature is reported to be rising. As such, in all the three provinces the percentage reached at least $85 \%$.

Household interviewees were also asked about their knowledge related to the concept of GHG emission (Table 1, Questions (3) and (4)), which is another important concept associated with climate change. Their answers are shown in Table 4. The percentage of farmers who have heard about the concept of GHG emission is less compared with that of hearing about the concept of global climate change. Indeed, according to the authors' data, as a whole, out of their sample of 620 farmers, only 123 farmers (or $19.8 \%$ of farmers in the rural China sample) reported that they heard of the concept of GHG emission. This means, of course, that most people in rural China have never heard of the concept of GHG emission. The Question (4) in Table 1 was a follow-up conditional on having answered "yes" for knowing of the concept of GHG emission. As shown in Table $4,35.8 \%$ of the respondents admitted there exists a 
Table 2

Summary Statistics of Farmers' Socio-economic Characteristics

\begin{tabular}{|c|c|c|c|c|}
\hline Characteristics & Guangdong & Shanxi & Qinghai & Total \\
\hline Samples & 240 & 180 & 200 & 620 \\
\hline \multirow[t]{2}{*}{ Household size/persons } & 5.35 & 4.69 & 4.43 & 4.86 \\
\hline & $(1.81)$ & $(1.59)$ & $(1.36)$ & $(1.66)$ \\
\hline \multirow[t]{2}{*}{ Wealth (value of durable consumption)/(10,000 CNY) } & 1.20 & 1.16 & 0.98 & 1.12 \\
\hline & $(1.73)$ & $(2.10)$ & $(0.96)$ & $(1.65)$ \\
\hline \multirow[t]{2}{*}{ Walking time to the village border/hours } & 0.61 & 0.73 & 0.41 & 0.58 \\
\hline & $(0.49)$ & $(0.64)$ & $(0.35)$ & $(0.52)$ \\
\hline \multirow[t]{2}{*}{ Average age of household head/years } & 50.76 & 51.33 & 51.31 & 51.10 \\
\hline & $(9.76)$ & $(10.01)$ & $(9.46)$ & $(9.74)$ \\
\hline \multirow[t]{2}{*}{ Average education of household head/years } & 7.98 & 6.50 & 5.82 & 6.85 \\
\hline & $(2.79)$ & $(3.21)$ & $(3.60)$ & $(3.32)$ \\
\hline \multirow[t]{2}{*}{ Share of families having female household head $(1=$ male $) / \%$} & 0.03 & 0.06 & 0.05 & 0.04 \\
\hline & $(0.16)$ & $(0.23)$ & $(0.22)$ & $(0.20)$ \\
\hline \multirow[t]{2}{*}{ Share of household head being a village cadre $(1=$ yes $) / \%$} & 0.15 & 0.08 & 0.21 & 0.15 \\
\hline & $(0.35)$ & $(0.27)$ & $(0.41)$ & $(0.35)$ \\
\hline \multirow[t]{2}{*}{ Farmland size $/ \mathrm{mu}^{\text {a) }}$} & 15.48 & 26.20 & 11.65 & 17.36 \\
\hline & $(33.01)$ & $(41.80)$ & $(7.61)$ & $(31.29)$ \\
\hline \multirow{2}{*}{ Number of land plots } & 13.00 & 5.52 & 6.83 & 8.84 \\
\hline & $(10.20)$ & $(4.44)$ & $(2.94)$ & $(7.74)$ \\
\hline
\end{tabular}

Note: Data from the authors' survey. Standard deviations are in parenthesis. ${ }^{\text {a) }} \mathrm{mu}$ is the most common measure for area of farmland in China. 1 ha $=15 \mathrm{mu}$.

Table 3

Farmers' Knowledge about Global Climate Change, 2011

\begin{tabular}{|c|c|c|c|c|c|}
\hline \multirow[t]{2}{*}{ Province } & \multirow{2}{*}{$\begin{array}{c}\text { Total samples } \\
\text { No. of obs. }\end{array}$} & \multicolumn{2}{|c|}{ Know the concept of global climate change } & \multicolumn{2}{|c|}{ Of which, think that the temperature discussed is rising } \\
\hline & & No. of obs. & $\%$ & No. of obs. & $\%$ \\
\hline & (1) & $(2)$ & $(3)=(2) /(1)$ & (4) & $(5)=(4) /(2)$ \\
\hline Total & 620 & 328 & 52.9 & 299 & 91.2 \\
\hline Guangdong & 240 & 114 & 47.5 & 99 & 86.8 \\
\hline Shanxi & 180 & 103 & 57.2 & 92 & 89.3 \\
\hline Qinghai & 200 & 111 & 55.5 & 108 & 97.3 \\
\hline
\end{tabular}

Note: Data from the authors' survey.

Table 4

Farmers' Knowledge about the Concept of GHG Emission, 2011

\begin{tabular}{|c|c|c|c|c|c|}
\hline \multirow[t]{2}{*}{ Province } & \multirow{2}{*}{$\begin{array}{c}\text { Samples } \\
\text { No. of obs. }\end{array}$} & \multicolumn{2}{|c|}{ Know the concept of GHG emission } & \multicolumn{2}{|c|}{ Of which, know the relationship between GHG emission and fertilizers application } \\
\hline & & No. of obs. & $\%$ & No. of obs. & $\%$ \\
\hline & (1) & (2) & $(3)=(2) /(1)$ & (4) & $(5)=(4) /(2)$ \\
\hline Total & 620 & 123 & 19.8 & 44 & 35.8 \\
\hline Guangdong & 240 & 45 & 18.8 & 13 & 28.9 \\
\hline Shanxi & 180 & 41 & 22.8 & 19 & 46.3 \\
\hline Qinghai & 200 & 37 & 18.5 & 12 & 32.4 \\
\hline
\end{tabular}

Note: Data from the authors' survey. 
relationship between GHG emission and chemical fertilizer application. That is, for those who know of the concept of GHG emission, chemical fertilizer application is indeed a contributing factor to the emission of GHG.

3.3 Perceptions of farmers towards climate change and variability

3.3.1 Perceptions of farmers towards long term climate change

In a household survey, the authors asked the following two sets of questions, farmers' perception on air temperature, precipitation and the frequency of extreme weather events in the past ten years (Table 1, Questions (6) $\pm(10)$ ). While these questions were difficult for many farmers answer in the initial time of the interviews, farmers did provide answers after careful thinking and recalling; despite this many answers might not be right and subject to personal experience. In a later study, the authors would like to see whether there is any co-relation between farmers' perception of climate change and their risk management behaviors. For this report simple statistical results are presented in Table 5.

The results show that farmers did perceive some changes in climate (Table 5). Most of the farmers $(82.9 \%)$ perceived that the air temperature has risen gradually in the past ten years. Only $5.6 \%$ and $9.2 \%$ of them perceived a decreasing trend and unchanged temperatures, respectively, in the same time period. Different from the air temperature change perception, the responses to the change of precipitation were diversified. More than half of the farmers $(54.7 \%)$ thought that the average precipitation in the past ten years has tended to decrease. The proportions of farmers who gave the answer of "increasing" was $23.4 \%$ and "unchanged" $16.5 \%$ precipitation were almost the same.

3.3.2 Perceptions of farmers towards short term extreme weather events.

One of the survey instruments was in particular designed to capture farmers' perceptions and understanding of the occurrence of extreme weather events. Questions were included to investigate whether farmers have noticed changes in the frequency of extreme weather events in the past ten years. The results show that farmers did perceive some changes in the occurrence of extreme weather events (Table 6). Most of the farmers (65.6\%) perceived that the frequency of drought increased in the past ten years. By comparison, however, about half of the farmers expressed that the frequency of flooding (48.1\%) and frost $(48.2 \%)$ over the last ten years did not change (Table 6). There were $20.6 \%$ (14.8\%) of the farmers who perceived a rising frequency of flood (frost) disasters, while the other $15.3 \%(24.0 \%)$ of the farmers thought the frequency of flood (frost) decreased over the past ten years.

The different perceptions of farmers on various climate events may imply that the occurrences of flood and frost disasters were not too severe, but drought occurred relatively more frequent in the past years. While there exists a view that farmers' perceptions may be based more on recent, short-term trends rather than long term changes (Gbetibouo, 2009), the perceptions of Chinese farmers might still reveal that, the area covered by this study has experienced increasingly severe and extreme drought conditions during recent years. In China, the agricultural damages attributed to drought have escalated in comparison to the development of the economy in recent decades (Shen, Wang, Hao, \& Gong, 2007).

Table 5

Farmers' Perceptions towards Climate Change

\begin{tabular}{|c|c|c|c|c|c|c|c|c|c|}
\hline & & \multicolumn{2}{|c|}{ Total } & \multicolumn{2}{|c|}{ Guangdong } & \multicolumn{2}{|c|}{ Shanxi } & \multicolumn{2}{|c|}{ Qinghai } \\
\hline & & No. of obs. & $\%$ & No. of obs. & $\%$ & No. of obs. & $\%$ & No. of obs. & $\%$ \\
\hline \multirow{5}{*}{$\begin{array}{l}\text { Panel A: Farmers' perceptions of changes } \\
\text { in temperature in the past } 10 \text { years }\end{array}$} & Total & 620 & 100 & 240 & 100.0 & 180 & 100 & 200 & 100 \\
\hline & Rising & 514 & 82.9 & 200 & 83.3 & 123 & 68.3 & 191 & 95.5 \\
\hline & Declining & 35 & 5.6 & 7 & 2.9 & 24 & 13.3 & 4 & 2.0 \\
\hline & No change & 57 & 9.2 & 27 & 11.3 & 26 & 14.4 & 4 & 2.0 \\
\hline & Unknown & 14 & 2.3 & 6 & 2.5 & 7 & 3.9 & 1 & 0.5 \\
\hline \multirow{5}{*}{$\begin{array}{l}\text { Panel B: Farmers' perceptions of changes } \\
\text { in precipitation in the past } 10 \text { years }\end{array}$} & Total & 620 & 100 & 240 & 100 & 180 & 100 & 200 & 100 \\
\hline & Rising & 145 & 23.4 & 33 & 13.8 & 77 & 42.8 & 35 & 17.5 \\
\hline & Declining & 339 & 54.7 & 129 & 53.8 & 65 & 36.1 & 145 & 72.5 \\
\hline & No change & 102 & 16.5 & 53 & 22.1 & 33 & 18.3 & 16 & 8.0 \\
\hline & Unknown & 34 & 5.5 & 25 & 10.4 & 5 & 2.8 & 4 & 2.0 \\
\hline
\end{tabular}

Note: Data from the authors' survey. 
Table 6

Farmers' Perceptions towards Extreme Weather Events (Drought, Frost, and Flood)

\begin{tabular}{|c|c|c|c|c|c|c|c|c|c|}
\hline & & \multicolumn{2}{|c|}{ Total } & \multicolumn{2}{|c|}{ Guangdong } & \multicolumn{2}{|c|}{ Shanxi } & \multicolumn{2}{|c|}{ Qinghai } \\
\hline & & No. of obs. & $\%$ & No. of obs. & $\%$ & No. of obs. & $\%$ & No. of obs. & $\%$ \\
\hline \multirow{5}{*}{$\begin{array}{l}\text { Panel A:Farmers' perceptions of } \\
\text { the drought frequency in the past } \\
10 \text { years }\end{array}$} & Total & 620 & 100 & 240 & 100 & 180 & 100 & 200 & 100 \\
\hline & Rising & 407 & 65.6 & 151 & 62.9 & 95 & 52.8 & 161 & 80.5 \\
\hline & Declining & 82 & 13.2 & 26 & 10.8 & 38 & 21.1 & 18 & 9 \\
\hline & No change & 113 & 18.2 & 54 & 22.5 & 40 & 22.2 & 19 & 9.5 \\
\hline & Unknown & 18 & 2.9 & 9 & 3.8 & 7 & 3.9 & 2 & 1 \\
\hline \multirow{5}{*}{$\begin{array}{l}\text { Panel B:Farmers' perceptions of the } \\
\text { frost frequency in the past } 10 \text { years }\end{array}$} & Total & 620 & 100 & 240 & 100 & 180 & 100 & 200 & 100 \\
\hline & Rising & 92 & 14.8 & 48 & 20 & 26 & 14.4 & 18 & 9 \\
\hline & Declining & 149 & 24 & 55 & 22.9 & 42 & 23.3 & 52 & 26 \\
\hline & No change & 299 & 48.2 & 106 & 44.2 & 91 & 50.6 & 102 & 51 \\
\hline & Unknown & 80 & 12.9 & 31 & 12.9 & 21 & 11.7 & 28 & 14 \\
\hline \multirow{5}{*}{$\begin{array}{l}\text { Panel C:Farmers' perceptions of the } \\
\text { flood frequency in the past } 10 \text { years }\end{array}$} & Total & 620 & 100 & 240 & 100 & 180 & 100 & 200 & 100 \\
\hline & Rising & 128 & 20.6 & 79 & 32.9 & 47 & 26.1 & 3 & 1.5 \\
\hline & Declining & 95 & 15.3 & 49 & 20.4 & 14 & 7.8 & 32 & 16 \\
\hline & No change & 298 & 48.1 & 90 & 37.5 & 94 & 52.2 & 114 & 57 \\
\hline & Unknown & 98 & 15.8 & 22 & 9.2 & 25 & 13.9 & 51 & 25.5 \\
\hline
\end{tabular}

Note: Data from the authors' survey.

\section{Risk response of farmers to climate change}

4.1 Farmers' attitudes towards risk responses to climate change.

The attitudes of farmers were evaluated in order to get a general impression of farmers' risk reactions towards the changes in climate (Table 1, Questions (11), (13) and (15)). In this paper the authors mainly focus on the farmers' crop adjustment behavior. As a risk management measure among adaptations made in response to climate change, adjusting crop patterns is found to be quite an important option adopted in farming practice (Mendelsohn, Nordhaus, \& Shaw, 1994). As such, adjustments in crop patterns in response to soil, temperature, rainfall, and other regionspecific characteristics are a major source of productivity growth in agriculture.

The results of the survey are presented in Table 7. About a quarter $(26 \%)$ of household interviewees reported that they would switch to other crops if the temperature is rising in the long run given all other conditions remain the same. This percentage is nearly the same for the other two situations: about $26 \%(24 \%)$ of respondents answered "yes" respectively, if precipitation is rising (or declining) in the long run given all other conditions stay the same. This result may imply that while the percentage is not high, Chinese farmers have a willingness to adjust their production behavior and avoid potential economic loss induced by climate change.
When it comes to the potential crops the farmers are willing to switch to (Table 1, Questions (12), (14) and (16)), the authors find that the responses vary among provinces (Table 8). For example, farmers in Guangdong and Qinghai tend to switch to plant maize, vegetable, and oil crops when temperatures are rising in the long run. However, farmers in Shanxi are more likely to switch to plant potato. If precipitation changes, for example, with more rain fall in the long run, farmers in Guangdong are willing to plant more rice. Farmers in Shanxi and Qinghai, however, would like to switch maize and wheat, respectively. It is reasonable because rice, maize and wheat are generally water-intensive grain crops. Interestingly, giving the declining precipitation in the long run, farmers also accordingly adjust the crops they are willing to switch to. The authors find that farmers in Guangdong are ready to plant more sweet potato and oil crops. Farmers in Shanxi and Qinghai tend to plant more potato and oil crops, respectively. This may be because all of the sweet potato, potato, and oil crops are relatively drought-tolerant and thus are more suitable for planting in the low-rain regions. This result empirically confirms that farmers are generally rational decision makers in response to environmental change. Overall, farmers are able to adjust their crop structure as a risk management measure to best adapt to the changing climate.

\subsection{Determinants of farmer risk responses to climate change}

What factors drive farmers to make risk responses under 
Table 7

Farmers' Risk Responses towards Climate Change

\begin{tabular}{|c|c|c|c|c|c|c|c|}
\hline \multirow[t]{2}{*}{ Province } & \multirow{2}{*}{$\begin{array}{c}\text { Samples } \\
\text { No. of obs. }\end{array}$} & \multicolumn{2}{|c|}{$\begin{array}{l}\text { If temperature is rising in the } \\
\text { long run, switch to other crops }\end{array}$} & \multicolumn{2}{|c|}{$\begin{array}{l}\text { If precipitation is rising in the } \\
\text { long run, switch to other crops }\end{array}$} & \multicolumn{2}{|c|}{$\begin{array}{l}\text { If precipitation is declining in the } \\
\text { long run, switch to other crops }\end{array}$} \\
\hline & & No. of obs. & $\%$ & No. of obs. & $\%$ & No. of obs. & $\%$ \\
\hline & (1) & (2) & $(3)=(2) /(1)$ & (4) & $(5)=(4) /(1)$ & (6) & $(7)=(6) /(1)$ \\
\hline Total & 620 & 161 & 26 & 163 & 26 & 148 & 24 \\
\hline Guangdong & 240 & 37 & 15 & 45 & 19 & 47 & 20 \\
\hline Shanxi & 180 & 39 & 22 & 41 & 23 & 34 & 19 \\
\hline Qinghai & 200 & 85 & 43 & 77 & 39 & 67 & 34 \\
\hline
\end{tabular}

Note: Data from the authors' survey.

Table 8

Potential Crops Farmers are Willing to Switch to under Climate Change

\begin{tabular}{|c|c|c|c|c|c|c|c|c|c|c|}
\hline & & Wheat & Maize & Rice & Sweet potato & Potato & Soybean & Vegetable & Oil crops & Sugar crops \\
\hline \multirow[t]{3}{*}{ Guangdong } & $\begin{array}{c}\text { Rising } \\
\text { temperature }\end{array}$ & 0 & 2 & 1 & 1 & 0 & 0 & 2 & 2 & 0 \\
\hline & $\begin{array}{c}\text { Rising } \\
\text { precipitation }\end{array}$ & 0 & 0 & 9 & 0 & 0 & 0 & 3 & 0 & 3 \\
\hline & $\begin{array}{l}\text { Declining } \\
\text { precipitation }\end{array}$ & 0 & 2 & 0 & 3 & 0 & 0 & 1 & 3 & 2 \\
\hline \multirow[t]{3}{*}{ Shanxi } & $\begin{array}{l}\text { Rising } \\
\text { temperature }\end{array}$ & 1 & 3 & 0 & 0 & 4 & 2 & 1 & 1 & 0 \\
\hline & $\begin{array}{c}\text { Rising } \\
\text { precipitation }\end{array}$ & 2 & 7 & 1 & 1 & 2 & 1 & 0 & 2 & 0 \\
\hline & $\begin{array}{l}\text { Declining } \\
\text { precipitation }\end{array}$ & 1 & 2 & 0 & 0 & 5 & 1 & 1 & 2 & 0 \\
\hline \multirow[t]{3}{*}{ Qinghai } & $\begin{array}{c}\text { Rising } \\
\text { temperature }\end{array}$ & 1 & 7 & 0 & 0 & 1 & 0 & 7 & 6 & 0 \\
\hline & $\begin{array}{c}\text { Rising } \\
\text { precipitation }\end{array}$ & 6 & 2 & 0 & 0 & 4 & 0 & 4 & 5 & 0 \\
\hline & $\begin{array}{l}\text { Declining } \\
\text { precipitation }\end{array}$ & 4 & 2 & 0 & 0 & 4 & 1 & 1 & 5 & 0 \\
\hline
\end{tabular}

Note: Data from the authors' survey. Samples include 240 in Guangdong, 180 in Shanxi, and 200 in Qinghai.

changing climate conditions? The authors' Probit regression results reported in Table 9 demonstrate that farmer characteristics significantly affect their risk reaction behaviors, while the results show some nuances under three climate change scenarios. For example, when temperatures are rising in the long run, the age of the household head could be an important factor influencing farmer's adaptive risk reaction (Table 9, column 1). It is found that households with younger heads and household heads with a higher education level, who generally have more knowledge on climate change, are more likely to react to risk. This confirms that farmers' knowledge and perceptions on climate change are relevant in determining their adaptation. The results also suggest that in rising temperatures families with greater wealth and more plots are less likely to make adaptations. These results confirm the concerns that the poor may be more vulnerable in the face of climatic shocks (Wang, Huang, \& Wang, 2014). Planting in different plots is itself a risk-aversion action, which thereby promotes producers to apply risk management measures. The significantly negative impact of walking time within the village implies that the residence dispersal might restrict the adaptation related to information spreading.

When precipitation is rising in the long run, the authors find that households with larger land tend to adapt (Table 9, column 2). Regarding farmers' reactions to the decreasing precipitation, the authors find that larger households in family size and farm size are also more willing to take risk reactions (Table 9, column 3). As such, households with younger heads are also more likely to adapt. This information suggests that household assets are important factors in determining farmers' risk reaction behaviors. 
Table 9

Determinants of Farmer Risk Reaction to Increasing Temperature, Increasing Precipitation, and Decreasing Precipitation

\begin{tabular}{|c|c|c|c|}
\hline Variables & (1) & (2) & (3) \\
\hline \multirow[t]{2}{*}{ Household size } & 0.009 & -0.006 & $0.019^{*}$ \\
\hline & $(0.011)$ & $(0.012)$ & $(0.011)$ \\
\hline \multirow[t]{2}{*}{ Age of household head } & $-0.007 * * *$ & -0.002 & $-0.005 * * *$ \\
\hline & $(0.002)$ & $(0.002)$ & $(0.002)$ \\
\hline \multirow[t]{2}{*}{ Education of household head } & $0.010^{*}$ & 0.009 & 0.009 \\
\hline & $(0.006)$ & $(0.006)$ & $(0.006)$ \\
\hline \multirow[t]{2}{*}{ Male of household head } & -0.082 & 0.003 & 0.074 \\
\hline & $(0.090)$ & $(0.086)$ & $(0.080)$ \\
\hline \multirow[t]{2}{*}{ Wealth (value of durable consumption)/(10,000 CNY) } & $-0.032 * *$ & -0.011 & -0.011 \\
\hline & $(0.015)$ & $(0.012)$ & $(0.012)$ \\
\hline \multirow[t]{2}{*}{ Farmland size/mu } & 0.000 & $0.002 * * *$ & $0.001 * *$ \\
\hline & $(0.001)$ & $(0.001)$ & $(0.001)$ \\
\hline \multirow[t]{2}{*}{ Number of land plots } & $-0.008 * *$ & -0.003 & -0.004 \\
\hline & $(0.003)$ & $(0.003)$ & $(0.003)$ \\
\hline \multirow[t]{2}{*}{ Walking time to the village border/hours } & $-0.044^{*}$ & -0.025 & -0.015 \\
\hline & $(0.026)$ & $(0.025)$ & $(0.017)$ \\
\hline Province dummies & yes & yes & yes \\
\hline pseudo $R^{2}$ & 0.103 & 0.051 & 0.049 \\
\hline
\end{tabular}

Note: Standard errors in parentheses. ${ }^{*} p<0.05,{ }^{* *} p<0.01,{ }^{* * *} p<0.001$.

\section{Concluding remarks}

The work presented in this paper is motivated by the authors' need to better understand the farmers' knowledge and perceptions on the changing climate, and then farmer adaptive behavior. The survey results show that farmers in Guangdong, Shanxi, and Qinghai in China are able to recognize that temperatures have increased and there has been a reduction in the volume of rainfall. Farmers also perceive that the frequency and severity of extreme weather events such as drought and flood are increasing. Although farmers are aware of climatic changes, few seem to take risk reactions to adapt. Only approximately $25 \%$ of farmers are willing to adjust their farming structures to account for the impacts of climate change. The Probit model is applied to examine the determinants of risk reaction to climate change. The results highlight that household size, wealth, farm size, the number of plots, and the degree of village dispersion are the factors that influence farmer adaptive capacity to climate change.

The above findings have a couple of policy and research implications. First, the knowledge and perceptions on climate change are important for farmers in their responses. Government policies should therefore ensure that farmers have access to information of climate change to increase their ability to change adaptation strategies in dealing with the forecasted climate conditions.

Second, improving farmers' adaptation capacity is important to cope with the changing climate. A crucial area to improve farmers' adaptive capacity is to improve farmers' education level. Moreover, as the household assets in term of wealth and farm size are also important determinants of applying risk reactions; it is a challenge to households in those vulnerable and poor regions where most farmers are poor and often lack sufficient capital to invest in changes. Enhancing the adaptive capabilities of these vulnerable regions in responding to climate risks should be of priority for policy interventions.

Finally, a great deal of interest also exists in analyzing the direct impact of perceptions on adaptation. To have more policy implications on adaptive risk management, more research efforts should be made in collecting data on dynamic perceptions on both climate change and extreme events.

Acknowledgements This research was financially supported by the Chinese Post-doctoral Science Fund (2015M570694), and the Major Projects from the National Fund of Social Sciences (15ZDA020) and the National Natural Science Foundation of China (71431006 and 71503276), and the Ministry of Education Fund of Social Sciences (13JZD016).

\section{References}

Bryan, E., Deressa, T.T., Gbetibouo, G., \& Ringler, C. (2009). Adaptation to climate change in Ethiopia and South Africa: options and constraints. Environmental Science \& Policy, 12, 413-426 
Byg, A., \& Salick, J. (2009). Local perspectives on a global phenomenon - Climate change in Eastern Tibetan villages. Global Environmental Change, 19, 156-166

Chen, H., Wang, J., \& Huang, J. (2014). Policy support, social capital, and farmers' adaptation to drought in China. Global Environmental Change, 24, 193-202

Deressa, T., Hassan, R., Ringler, C., Alemu, T., \& Yesuf, M.M. (2009). Determinants of farmers' choice of adaptation methods to climate change in the Nile Basin of Ethiopia. Global Environmental Change, 19, 248-255

Deschênes, O., \& Greenstone, M. (2007). The economic impacts of climate change: evidence from agricultural output and random fluctuations in weather. American Economic Review, 97, 354-385

Di Falco, S., Veronesi, M., \& Yesuf, M. (2011). Does adaptation provide food security? A micro perspective from ethiopia. American Journal of Agricultural Economics, 93, 829-846

ECSNCCA (Edition Committee of the Second National Climate Change Assessment). (2011). Second national climate change assessment report. Beijing: Science Press

FAO (Food and Agriculture Organization). (2007). Adaptation to climate change in agriculture, forestry and fisheries: perspective, framework and priorities. Rome: Report of the FAO Interdepartmental Working Group on Climate Change

Frank, E., Eakin, H., \& López-Carr, D. (2011). Social identity, perception and motivation in adaptation to climate risk in the coffee sector of Chiapas, Mexico. Global Environmental Change, 21, 66-76

Gbetibouo, G.A. (2009). Understanding farmers' perceptions and adaptations to climate change and variability: the case of the Limpopo Basin, South Africa. Washington D.C.: International Food Policy Research Institute

Holst, R., Yu, X., \& Grun, C. (2013). Climate change, risk and grain yields in China. Journal of Integrative Agriculture, 12, 1279-1291

Huang, J., Wang, Y., \& Wang, J. (2015). Farmer's adaptation to extreme weather events through farm management and its impacts on the mean and risk of rice yield in China. American Journal of Agricultural Economics, 97, 602-617

IPCC (Intergovernmental Panel on Climate Change). (2014a). Climate change 2013-The physical science basis: working group I to the fifth assessment report of the intergovernmental panel on climate change. Cambridge, UK: Cambridge University Press

IPCC (Intergovernmental Panel on Climate Change). (2014b). Climate change 2014-Impacts, adaptation, and vulnerability: working group
II to the fifth assessment report of the intergovernmental panel on climate change. Cambridge, UK: Cambridge University Press

Maddison, D. (2007). The perception of an adaptation to climate change in Africa (World Bank Policy Research Working Paper, Number 4308). Washington, D.C.: The World Bank

Mendelsohn, R., \& Dinar, A. (2009). Climate change and agriculture: an economic analysis of global impacts, adaptation, and distributional effects. Cheltenham, UK: Edward Elgar Publishing

Mendelsohn, R., Nordhaus, W., \& Shaw, D. (1994). The impact of global warming on agriculture: a ricardian analysis. American Economic Review, 84, 753-771

NBSC (National Bureau of Statistics in China). (2012). China statistical yearbook 2012. Beijing: China Statistical Press

NDRC (National Development and Reform Commission). (2012). China's policies and actions for addressing climate change. Beijing: National Development and Reform Commission

Piao, S., Ciais, P., Huang, Y., Shen, Z., Peng, S., Li, J., Zhou, L., Liu, H., Ma, Y., Ding, Y., et al. (2010). The impacts of climate change on water resources and agriculture in China. Nature, 467, 43-51

Schlenker, W., \& Roberts, M. (2009). Nonlinear temperature effects indicate severe damages to U.S. crop yields under climate change. Proceedings of the National Academy of Sciences of the United States of America, 106, 15594-15598

Shen, C., Wang, W., Hao, Z., \& Gong, W. (2007). Exceptional drought events over eastern China during the last five centuries. Climatic Change, 85, 453-471

Smit, B., \& Skinner, M. (2002). Adaptation options in agriculture to climate change: a typology. Mitigation and Adaptation Strategies for Global Change, 7, 85-114

Tucker, C., Eakin, H., \& Castellanos, E. (2010). Perceptions of risk and adaptation: coffee producers, market shocks, and extreme weather in Central America and Mexico. Global Environmental Change, 20, $23-$ 32

Wang, J., Mendelsohn, R., Dinar, A., Huang, J., Rozelle, S., \& Zhang, L. (2009). The impact of climate change on China's agriculture. Agricultural Economics, 40, 323-337

Wang, Y., Huang, J., \& Wang, J. (2014). Household and community assets and farmers' adaptation to extreme weather event: the case of drought in China. Journal of Integrative Agriculture, 13, 687-697

Xiong, W., Conway, D., Lin, E., \& Holman, I. (2009). Potential impacts of climate change and climate variability on China's rice yield and production. Climate Research, 40, 23-35 